\title{
PENGARUH BEBERAPA DOSIS DAN JENIS EKSTRAK LARVASIDA ALAMI TERHADAP KEMATIAN LARVA NYAMUK Aedes aegypti
}

\author{
WIRA DESY KUSUMAWATI *), AGUS SUBAGIYO **), MELA FIRDAUST**)
}

\author{
Jurusan Kesehatan Lingkungan Politeknik Kesehatan Kemenkes Semarang, \\ Jl. Raya Baturaden KM 12 Purwokerto, Indonesia
}

\begin{abstract}
Abstrak
XV+104 halaman : gambar, tabel, grafik, lampiran

Penggunaan larvasida sintesis sangat merugikan masyarakat, seperti pencemaran lingkungan dan menyebabkan resistensi. Alternatif untuk mengurangi dampak negatif tersebut adalah dengan menggunakan larvasida nabati yang berasal dari tanaman yaitu daun sirsak (Annona muricata Linn) dan batang serai (Andropogon nardus). Tujuan penelitian ini untuk mengetahui efektivitas larvasida alami ekstrak daun sirsak (Annona muricata Linn) dan ekstrak batang serai (Andropogon nardus) terhadap kematian larva nyamuk Aedes aegypti, pengaruh dosis larvasida alami, jenis larvasida alami, adanya interaksi beberapa dosis dan jenis ekstrak.

Jenis penelitian yang digunakan eksperimen murni sedangkan untuk pelaksanaan penelitian menggunakan rancangan post test only control group. Populasi dalam penelitian ini adalah seluruh larva nyamuk Aedes aegypti instar III. Sampel berjumlah 1250 ekor larva. Analisis data yang dilakukan secara univariat dan bivariat (menggunakan uji anova dua jalan, dengan $\langle=0,05$ )

Kesimpulan dari penelitian ini adalah adanya pengaruh antara beberapa dosis ekstrak larvasida alami terhadap kematian larva nyamuk Aedes aegypti ditunjukkan dengan perbandingan antara mean kelompok yang mendapat perlakuan dengan diberi ekstrak daun sirsak 9,15 lebih baik dari pada mean diberi ektrak batang serai 7,1. Terdapat pengaruh jenis ekstrak larvasida alami terhadap kematian larva nyamuk Aedes aegypti bahwa $\mathrm{F}=$ 4,465 dengan porbalitas $0.043<0,05$ sedangkan interaksi antara beberapa dosis dan jenis ekstrak larvasida alami terhadap kematian larva nyamuk Aedes aegypti $\mathrm{F}=0,916$ dengan porbabilitas 0,037<0,05.

Saran yang diberikan kepada masyarakat yaitu diharapakan adanya penggunaan ekstrak daun sirsak (Annona muricata Linn) ini sangat mudah untuk mengaplikasikannya cukup menambahkan ekstrak daun sirsak ini kedalam penampungan air.
\end{abstract}

Daftar bacaan :22 (1992 - 2016)

Kata kunci : larvasida alami, Kematian Larva Nyamuk Aedes aegypty

Klasifikasi : -

$\mathrm{XV}+104$ pages : Image, tables, graph, attachments

The use of larvicide synthesis is very detrimental to society, such as environmental pollution and causing resistance. The alternative to reduce the negative impact is by using plant-based vegetable larvasida soursop leaves (Annona muricata Linn) and lemongrass (Andropogon nardus). The purpose of this research is to know the effectiveness of natural larvacide of soursop leaf extract (Annona muricata Linn) and lemongrass stem extract (Andropogon nardus) to death of Aedes aegypti mosquito larvae, effect of natural larvicidal dose, natural larvacide type, multiple dose interaction and extract type.

The type of research used purely experiment while for the implementation of research using post test only control group design. Population in this research is all larva of Aedes aegypti mosquito instar III. The sample amounted to 1250 larvae. Univariate and bivariate data analysis (using two way anova test, with $\langle=0,05$ )

The conclusion of this research is the effect of several doses of natural larvacidic extract on the death of Aedes aegypti mosquito larvae shown by comparison between mean group treated with soursop leaf extract 9.15 is better than mean given lemongrass stem extract 7.1. The effect of natural larvacide extract on Aedes aegypti mosquito larvae mortality that $\mathrm{F}=4,465$ with porbality $0.043<0.05$ while interaction between several doses and natural larvacidal extract type to Aedes aegypti mosquito larvae death $\mathrm{F}=0,916$ with porbability 0.037<0,05.

Suggest given to the people is expect the use of soursop leaf extract (Annona muricata Linn) It's very easy to apply this way. Just adding the soursop leaf extract into the water reservoir.

Daftar bacaan :21 (1992 - 2016)

Kata kunci : Natural Larvacide, Death of Aedes aegypty Mosquito Larvae

Classification : -

*wiradesykusumawati@gmail.com

**agusgiyo@yahoo.co.id

***melafirdaust@yahoo.co.id

\section{Pendahuluan}


DBD (Demam Berdarah Dengue) adalah penyakit yang disebabkan oleh infeksi virus dengue melalui vektor nyamuk Aedes spp. Penyakit ini merupakan salah satu penyakit menular yang berbahaya dan dapat menimbulkan kematian dalam waktu singkat. Virus penyakit DBD termasuk dalam kelompok Arthropod Borne Virus (Arboviroses) yang dikenal sebagai genus Flavivirus, famili Flaviviridae dengan 4 jenis serotipe, yaitu; DEN-1, DEN-2, DEN-3, DEN-4 (Supriyadi, 2012). Tanda - tanda penderita DBD pada umumnya adalah panas mendadak secara terus menerus selama 5-7 hari, lemah, nyeri, timbul bintik - bintik merah, dan terjadi pendarahan (Suyanto, et al : 2011).

Di Indonesia pada tahun 1968 penyakit Demam Berdarah Dengue di laporkan di Surabaya dan Jakarta sebanyak 58 kasus, dengan jumlah kematian yang sangat tinggi 24 orang (Case fatality rate $41,3 \%)$. Epidemi penyakit DBD diluar Jawa pertama kali dilaporkan di Sumatera Barat dan Lampung tahun 1972. Sejak itu, penyakit ini semakin menyebar luas ke berbagai wilayah di Indonesia. Jumlah kasus DBD di Indonesia terus meningkat, baik dalam jumlah maupun luas wilayah yang terjangkit dan secara sporadis selalu terjadi kejadian luar biasa (KLB) setiap tahun. Berdasarkan pada situasi di atas, WHO menetapkan Indonesia sebagai salah satu negara hiperendemik dengan jumlah provinsi yang terkena DBD sebanyak 32 provinsi dari 33 provinsi di Indonesia dan 355 kabupaten atau kota dari 444 kota terkena DBD. Setiap hari dilaporkan, sebanyak 380 kasus DBD dan 1 - 2 orang meninggal setiap hari (A. Arsunan Arsin, 2013).

Laporan kegiatan pemberantasan penyakit Demam Berdarah dengue oleh Dinas Kesehatan Propinsi Jawa Tengah pada tahun 2015, telah terjadi peningkatan jumlah penderita, Incidence Rate (IR) dan Case Fatality Rate (CFR). Jumlah kasus DBD pada tahun 2014 meningkat 6,7\% menjadi 1.737 penderita pada tahun 2015 meningkat $6,7 \%$ dari sebelumnya 92,45 menjadi 98,61 jumlah penderita DBD yang meninggal dari 27 orang pada tahun 2014 menjadi 21 orang pada tahun 2015. Sejak tahun 1994 sampai dengan 2015 jumlah kasus dan kematian tertinggi pada tahun 2010 yaitu 5.556 kasus dan 47 meninggal. IR tertinggi juga pada tahun 2010 yaitu 368,7 per 100.000 dan CFR tertinggi pada tahun 2006 yaitu $2,28 \%$.

Incidence Rate (IR) DBD Kota Semarang dari Tahun 2006 sampai dengan tahun 2015 selalu jauh lebih tinggi dari IR DBD Jawa Tengah dan IR DBD Nasional. Target Nasional pencapaian incidence rate $\mathrm{DBD}$ adalah $\leq 51$ per 100 ribu penduduk.
Incidence Rate DBD Kota Semarang tahun 2015 menduduki peringkat ketiga IR DBD Jawa Tengah setelah kota Magelang dan Kabupaten Jepara (DKK Semarang, 2015 : 44). Berbagai upaya telah dilakukan oleh pemerintah untuk mengendalikan penyakit DBD yaitu Pemantauan Jentik Rutin (PJR), Pemantauan Jentik Berkala (PJB), Pemberantasan Sarang Nyamuk (PSN) melalui 3M plus (Menguras, Menutup, dan Mengubur), plus menabur larvasida, penyebaran ikan pada tempat penampungan air, serta kegiatan - kegiatan lainnya yang dapat mencegah memberantas nyamuk Aedes berkembang biak (Kemenkes RI, 2010 : 115).

Pemberantasan larva Ae.aegypti digunakan sebagai salah satu cara yaitu dengan menggunakan insektisida kimia. Saat ini larvasida yang paling luas digunakan untuk menggendalikan larva Ae.aegypti adalah temefos 1\% (abate 1SG). Sejak tahun 1980 abate telah dipakai secara masal untuk program pemberantasan larva Ae.aegypti di Indonesia. Apabila penggunaan insektisida kimia dilakukan secara terus-menerus, maka akan menimbulkan dampak negatif terhadap organisme hidup maupun lingkungan sekitar. Kandungan bahan aktif dari temephos seperti Tetramethyil Thiodi.P-Phenylene, Phasphorothioate $1 \%$ dan inert ingredient 99\% merupakan bahan kimia yang jika digunakan terlalu lama dapat bersifat toksik. Menurut WHO, kurang lebih 20.000 orang mati per tahun akibat keracunan insektisida. Selain itu, penggunaan insektisida kimia dapat mengganggu kualitas dan keseimbangan lingkungan hidup akibat adanya residu serta timbulnya resistensi pada hewan sasaran. (R. Panghiyangani, et.al : 2012)

Perihal di atas sehingga perlu adanya suatu usaha untuk mendapatkan larvasida alternatif yaitu, menggunakan larvasida alami. Larvasida alami merupakan larvasida yang terbuat dari tanaman yang mempunyai kandungan beracun terhadap serangga pada stadium larva. Penggunaan larvasida alami, diharapkan tidak mempunyai efek samping terhadap lingkungan, manusia, dan tidak menimbulkan resistensi bagi serangga.

Ada dua jenis tanaman yang mempunyai potensi sebagai sumber larvasida nabati yaitu Daun Sirsak (Annona muricuta Linn) dan Serai (Andropogon nardus). Kedua tanaman tersebut memiliki daya bunuh yang berbeda jika ditinjau dari kandungan yang dimiliki oleh masing-masing taman. Tanaman sirsak (Annona muricata Linn) merupakan tanaman yang dapat digunakan sebagai obat - obatan tradisional untuk menyembuhkan 
berbagai macam penyakit, mulai dari penyakit yang ringan sampai penyakit yang berat. Bagian tanaman sirsak yang dapat dimanfaatkan yaitu buah, daun, akar, biji, bunga, dan kulit batang. Selain dapat digunakan sebagai obat - obatan tradisional, daun sirsak mengandung bahan aktif saponin, flavonoid, tanin dan alkaloid yang mempunyai kemampuan untuk membunuh larva nyamuk Aedes aegypti (Bahila, et.al : 2015).

Tanaman sirsak (Annona muricuta Linn), di Indonesia juga tumbuh beberapa jenis tanaman yang memiliki manfaat salah satunya (Andropogon nardus) tumbuhan serai sering digunakan masyarakat untuk mengusir nyamuk dan dapat menghambat pertumbuhan dan mematikan larva Aedes aegypti. Serai mengandung senyawa alamiah seperti minyak atsiri yang terdiri dari sitral, sitronela, geraniol, mirsera, nerol, farsenol, methyl heptenon eugenol methyleter, kadinen, kadinol, limonen dan dipentema. Kandungan kimia tanaman serai yang paling besar yaitu Senyawa Sitronela yaitu sebesar $85 \%$ dan mempunyai sifat racun dehidrasi (Desiccant), racun tersebut merupakan racun kontak yang dapat mengakibatkan kematian karena kehilangan cairan terus menerus. (Nadyawatie Warganegara : 2014)

\section{Bahan dan Metode}

Jenis penelitian ini adalah penelitian eksperimen murni (true eksperiment). sedangkan untuk pelaksanaan penelitian menggunakan rancangan post test only control group yaitu suatu rancangan percobaan yang terdiri dari dua kelompok yaitu kelompok kontrol dan kelompok eksperimen. Perlakuan hanya diberikan pada\% kematian larva uji = kelompok eksperimen.

Hanifah Kemas Ali (1993) dalam Sri

Wahyuni (2005) untuk menghindari kesalahan Apabila angka kematian pada kelompok kontrol kurang dari sekecil mungkin, maka banyaknya ulangan dan perlakuan dalam eksperimen dihitung dengan menggunakan rumus sebagai berikut :

$$
\begin{aligned}
(t-1)(r-1) & \geq 15 \\
(6-1)(r-1) & \geq 15 \\
65(r-1) & \geq 15 \\
5 r-5 & \geq 15 \\
5 r & \geq 15+5 \\
5 r & \geq 20 \\
r & \geq 20 \div 5 \\
r & \geq 4 \\
r & =4
\end{aligned}
$$

Keterangan :

$\mathrm{r}=$ jumlah replikasi,

$\mathrm{t}=$ jumlah perlakuan $(6)$

Berdasarkan penghitungan tersebut, maka replikasi dilakukan pada masing - masing perlakuanBerdasarkan uji pendahuluan tersebut didapati penelitian sebanyak 4 kali replikasi.
Besar sampel yang digunakan 25 ekor larva nyamuk pada setiap perlakuan pada masing masing dosis. Jumlah nyamuk keseluruhan adalah 1250 ekor nyamuk Aedes aegypti untuk 2 dosis ekstrak daun sirsak dengan dosis ekstrak batang serai. Dengan perhitungan 25 ekor x jumlah dosis yang digunakan $\mathrm{x}$ jumlah pengulangan $\mathrm{x} 2$ ekstrak uji coba $=25 \times 6 \times 4 \times 2=1200$ ekor, sedangkan 50 ekor sebagai persediaan jika larva nyamuk sebagai bahan uji mati.

Populasi dalam penelitian ini yaitu larva nyamuk Aedes aegypti yang dipelihara di Laboratorium Biologi, jurusan Kesehatan Lingkungan, Poltekkes Kemenkes semarang.

Data umum penelitian ini yaitu penggunaan ekstrak daun sirsak (Annona muricata Linn) dan ekstrak batang serai (Andropogon nardus) dalam membunuh larva nyamuk Aedes aegypti di Laboratorium Biologi, jurusan Kesehatan Lingkungan, Poltekkes Kemenkes Semarang.

Data khusus dalam penelitian ini yaitu jumlah larva nyamuk Aedes aegypti yang mati setelah diberikan ekstrak daun sirsak (Annona muricata Linn) dan ekstrak batang serai (Andropogon nardus).

Data yang diperoleh dengan menghitung jumlah larva Aedes aegypti yang mati setelah diberi ekstrak daun sirsak (Annona muricata Linn) dengan ekstrak batang serai (Andropogon nardus). Perhitungan persentase kematian larva uji dihitung dengan menggunakan rumus sebagai berikut :

\section{$\Sigma$ larva uji yang mati}

\section{$\sum$ larva uji} 5\% maka diabaikan. Apabila angka kematian pada kelompok kontrol antara 5\% - 20\% maka dikoreksi dengan rumus Abbot, yaitu :

$$
\begin{array}{ll} 
& \text { A }-C \\
\text { A1 }=\quad & \text { x } 100 \% \\
& 100-C \\
\text { Keterangan : } \\
\text { A1 } \quad=\text { kematian setelah koreksi } \\
\text { A } \quad=\text { kematian pada perlakuan } \\
\text { C } \quad=\text { kematian pada kontrol }
\end{array}
$$

Besar dosis larvasida ekstrak daun sirsak dan ekstrak batang serai yang digunakan yaitu

Dari uji pendahuluan yang dilakukan oleh Sugeng Juwono Mardhihusodo menggunakan kisaran konsentrasi bahan uji yang membunuh serangga uji antara 10 $90 \%$ dengan dosis $0,2 \mathrm{ml}, 0,1 \mathrm{ml}, 0,02 \mathrm{ml}$ dan 0 dengan masa pemaparan 24 jam.

lanjutan dengan menggunakan dosis yaitu 4ml, 
8ml, 12ml, 16ml, 20ml dan 0 dengan masing masing empat kali replikasi, dilakukan selama 24 jam pemaparan. Dari hasil analisis probit dengan $\mathrm{LC}_{50}$ didapat dosis sebesar $6,89 \%$ dengan masa pemaparan 24 jam sebesar 5,58\% dimana infusa $10 \%$ terbukti bedaya insektisida.

a. Cara Pembuatan Larvasida Ekstrak Daun Sirsak dan Ekstrak Batang Serai

1. Daun sirsak dan batang serai dicuci sampai bersih dengan air, untuk membersihkan kotoran yang melekat.

2. Daun sirsak dan batang serai yang sudah dicuci ditiriskan sampai kering. Daun sirsak dan batang serai yang sudah ditiriskan diiris tipis, dikeringkan dengan cara diangin - anginkan (tidak langsung dibawah sinar matahari)

3. Daun sirsak dan batang serai yang telah kering dihaluskan dengan menggunakan blender dan diayak.

4. Daun sirsak dan batang serai yang telah dihaluskan dimasukkan ke dalam labu leher 3 , kemudian ditambah aquades.

5. Pendingin balik dan termometer dirangkai pada labu leher 3 dipanaskan dengan penangas air selama 3 jam pada suhu $100^{\circ} \mathrm{C}$.

6. Penangas air dimatikan dan campuran hasil didinginkan selama 2 hari 24 jam.

7. Campuran disaring, filtrat yang dihasilkan ekstrak daun sirsak dan ekstrak batang serai.

\section{b. Pengujian Kematian Larva Aedes Aegypti}

1. Membuat larvasida ekstrak daun sirsak dan ekstrak batang serai dengan metode infusa dilaboratorium sesuai dengan jumlah yang telah ditentukan sebelumnya.

2. Memasukkan jentik dengan menggunakan pipet jentik ke dalam cup uji coba,

3. Meneteskan ekstrak daun sirsak dan ekstrak batang serai kedalam cup uji coba yang berisikan 25 larva nyamuk Aedes aegypti pada jam 1, 2, 3, 4, 5, dan ke 6 .

4. menghitung hasil pengamatan.

\section{Hasil dan Pembahasan}
A. Gambaran Umum Jurusan Kesehatan Lingkungan
1. Profil dan Kondisi Geografi
Nama Lokasi : Laboratorium Biologi Jurusan Kesehatan Lingkungan Purwokerto

Alamat Lokasi : Jl. Raya Baturaden Km. 12 Telp./Fax. 0281-681709 Purwokerto, Jawa Tengah

Luas dan Volume

:416 $\mathrm{m}^{2}$ dan 201,42 $\mathrm{m}^{3}$

Laboratorium Biologi

Ketinggian tanah dari : $540 \mathrm{M}$

permukaan laut

Banyaknya curah hujan :450 MM / Tahun

Suhu Udara Rata-rata : $28^{\circ} \mathrm{C}$

Topografi : Dataran Tinggi

\section{Laboratorium Biologi Jurusan Kesehatan Lingkungan Purwokerto}

Laboratorium Kampus 7

Poltekkes Kemenkes Semarang Jurusan Kesehatan Lingkungan Purwokerto didirikan pada tanggal 1 Januari 1979 yang berfungsi untuk pembelajaran mahasiswa Jurusan Kesehatan Lingkungan serta melayani pemeriksaan sampel untuk kepentingan penelitian dosen dan mahasiswa. Laboratorium Kampus 7 Poltekkes Kemenkes Semarang Jurusan Kesehatan Lingkungan Purwokerto berada di Kampus 7 Poltekkes Semarang Jalan Raya Baturraden KM 12 Kotak pos 148 Telp/Fax : 0281-681709 Desa Karangmangu, Kecamatan Baturraden, Purwokerto. Aktivitas di Laboratorium Kesehatan Lingkungan dimulai dari pukul 08.00 WIB sampai 16.00 WIB.

$$
\text { Laboratorium Kampus }
$$

Poltekkes Kemenkes Semarang Jurusan Kesehatan Lingkungan dibagi menjadi lima bagian diantaranya adalah laboratorium Mikrobiologi, Kimia, K3, Fisika, Biologi termasuk didalamnya parasitologi, Entomologi dan Vektor. Kemampuan Laboratorium Jurusan Kesehatan Lingkungan yaitu mampu melakukan kegiatan praktikum dari semua bidang studi yang didalamnya terdapat pembelajaran praktikum baik dilaboratorium maupun di workshop.

\section{Hasil Pengukuran Suhu}

Berikut ini adalah hasil pengukuran suhu awal dan akhir media pada penelitian.

Tabel 4.1 Hasil Pengukuran Suhu Ekstrak Daun Sirsak dan Ekstrak Batang Serai

\begin{tabular}{|c|c|c|c|c|c|c|}
\hline $\begin{array}{c}\text { Sirsak } \\
(500 \mathrm{ml} / 100 \mathrm{~mL})\end{array}$ & 25 & 25 & 25 & 25 & 25 & 25 \\
\hline $\begin{array}{c}\text { Serai } \\
(500 \mathrm{ml} / 100 \mathrm{~mL})\end{array}$ & 25 & 25 & 25 & 25 & 25 & 25 \\
\hline
\end{tabular}


suhu dapat stabil pada $25^{\circ} \mathrm{C}$. Hal ini merupakan suhu yang dapat digunakan larva Aedes aegypti berkembang dengan baik.

\section{Hasil Pengukuran pH}

Berikut ini adalah hasil pengukuran $\mathrm{pH}$ awal dan $\mathrm{pH}$ akhir media pada penelitian.

Tabel 4.2 Hasil Pengukuran pH Ekstrak Daun sirsak Dan Ekstrak Batang Serai

\begin{tabular}{ccccccc}
\hline $\begin{array}{c}\text { Sirsak } \\
(500 \mathrm{ml} / 100 \mathrm{~mL})\end{array}$ & 5 & 5 & 5 & 5 & 5 & 5 \\
\hline $\begin{array}{c}\text { Serai } \\
(500 \mathrm{ml} / 100 \mathrm{~mL})\end{array}$ & 5 & 5 & 5 & 5 & 5 & 5 \\
\hline
\end{tabular}
ektrak daun sirsak yaitu 5 , dan setelah diberi ekstak batang Serai yaitu 5 .

\section{A. Hasil Penelitian}

Jumlah larva setiap tabung uji adalah 25 ekor. Jumlah sampel masingmasing kelompok perlakuan dengan replikasi sebanyak empat kali adalah 100 ekor. Jumlah total sampel untuk lima kelompok perlakuan adalah 500 ekor larva. Rata-rata kematian larva untuk masing-masing kelompok perlakuan diperoleh dengan menghitung total jumlah kematian setiap kelompok perlakuan sebanyak empat kali replikasi dan kemudian membaginya dengan jumlah replikasi. Jumlah larva Aedes aegypti yang mati dalam setiap tabung untuk setiap Dosis ekstrak daun sirsak dan batang serai ditunjukkan pada tabel 4.3.

Hasil yang tercantum pada tabel 4.3 digunakan sebagai acuan penentuan dosis pada uji utama yaitu melihat dosis mana yang menunjukkan kematian 50\% larva $\left(\mathrm{LC}_{50}\right)$. Adapun kriteria larva mati pada saat perlakuan adalah larva yang tidak bergerak dan tidak merespon ketika disentuh serta larva yang sudah setengah mati.

\section{Diskripsi Data}

Data lengkap yang terkumpul sebagai hasil penelitian adalah sebagai berikut:

Tabel 4.3 Rangkuman Data Hasil Penelitian

\begin{tabular}{|c|c|c|c|c|c|}
\hline \multicolumn{6}{|c|}{ Ekstrak Batang Serai } \\
\hline $\begin{array}{c}\text { Do } \\
\text { sis }\end{array}$ & $\begin{array}{c}\text { Re } \\
\text { plik } \\
\text { asi }\end{array}$ & $\begin{array}{c}\text { Total } \\
\text { larva }\end{array}$ & $\begin{array}{c}\text { Jmlh } \\
\text { larva } \\
\text { mati }\end{array}$ & $\begin{array}{c}\text { Rata- } \\
\text { rata }\end{array}$ & $\begin{array}{c}\% \\
\text { Mortali } \\
\text { tas }\end{array}$ \\
\hline 0 & 0 & 25 & 0 & 0,0 & 0 \\
$\mathrm{ml}$ & & & & & \\
\hline 4 & 1 & 25 & 0 & 0,02 & 2 \\
$\mathrm{ml}$ & 2 & 25 & 1 & & \\
& 3 & 25 & 1 & & \\
& 4 & 25 & 0 & & \\
\hline
\end{tabular}

\begin{tabular}{|c|c|c|c|c|c|}
\hline 8 & 1 & 25 & 0 & 0,02 & 2 \\
$\mathrm{ml}$ & 2 & 25 & 1 & & \\
& 3 & 25 & 0 & & \\
& 4 & 25 & 1 & & \\
\hline 12 & 1 & 25 & 1 & 0,07 & 7 \\
$\mathrm{ml}$ & 2 & 25 & 1 & & \\
& 3 & 25 & 2 & & \\
& 4 & 25 & 3 & & \\
\hline 16 & 1 & 25 & 2 & 0,27 & 27 \\
$\mathrm{ml}$ & 2 & 25 & 3 & & \\
& 3 & 25 & 8 & & \\
& 4 & 25 & 14 & & \\
\hline 20 & 1 & 25 & 4 & 0,37 & 37 \\
$\mathrm{ml}$ & 2 & 25 & 5 & & \\
& 3 & 25 & 11 & & \\
& 4 & 25 & 17 & & \\
\hline
\end{tabular}

\begin{tabular}{|c|c|c|c|c|c|}
\hline \multicolumn{7}{|c|}{ Ekstrak Daun Sirsak } \\
\hline \multirow{2}{*}{ Dosis } & $\begin{array}{c}\text { Repli } \\
\text { kasi }\end{array}$ & $\begin{array}{c}\text { Tot } \\
\text { al } \\
\text { lar } \\
\text { va }\end{array}$ & $\begin{array}{c}\text { Jmlh } \\
\text { larva } \\
\text { mati }\end{array}$ & $\begin{array}{c}\text { Rata } \\
\text {-rata }\end{array}$ & $\begin{array}{c}\text { M } \\
\text { Mortali } \\
\text { tas }\end{array}$ \\
\hline 0 & 0 & 25 & 0 & 0,0 & 0 \\
\hline $4 \mathrm{ml}$ & 1 & 25 & 0 & 0,02 & 2 \\
& 2 & 25 & 1 & & \\
& 3 & 25 & 1 & & \\
& 4 & 25 & 0 & & \\
\hline $8 \mathrm{ml}$ & 1 & 25 & 0 & 0,04 & 4 \\
& 2 & 25 & 1 & & \\
& 3 & 25 & 1 & & \\
& 4 & 25 & 2 & & \\
\hline $12 \mathrm{ml}$ & 1 & 25 & 2 & 0,16 & 16 \\
& 2 & 25 & 3 & & \\
& 3 & 25 & 5 & & \\
& 4 & 25 & 6 & & \\
\hline $16 \mathrm{ml}$ & 1 & 25 & 3 & 0,43 & 43 \\
& 2 & 25 & 8 & & \\
& 3 & 25 & 15 & & \\
& 4 & 25 & 17 & & \\
\hline $20 \mathrm{ml}$ & 1 & 25 & 5 & 0,61 & 61 \\
& 2 & 25 & 15 & & \\
& 3 & 25 & 17 & & \\
& 4 & 25 & 24 & & \\
\hline
\end{tabular}

Hasil pada tabel 4.3, menunjukkan bahwa kematian larva mengalami peningkatan sejalan dengan besarnya dosis ekstrak larvasida alami yang diberikan pada kedua kelompok perlakuan. Persentase kematian larva menunjukkan lebih dari 50\% terdapat pada kelompok dengan diberi ekstrak daun sirsak pada dosis sebesar $20 \mathrm{ml}$. Berikut gambar grafik persentase kematian larva Aedes aegypti pada setiap kelompok dosis dan jenis larvasida. 


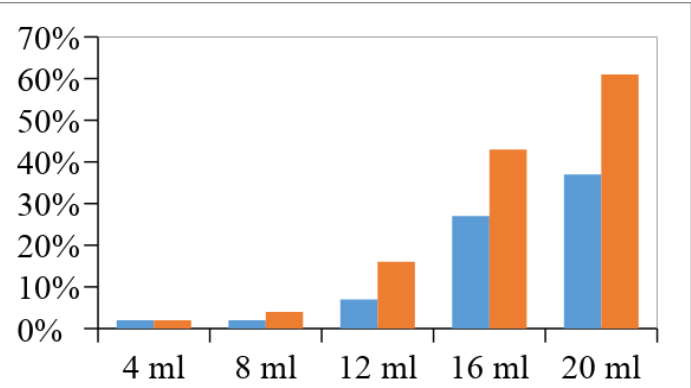

Gambar 4.1 Grafik Persentase Kematian Larva Aedes aegypti pada setiap Kelompok Dosis

Berdasarkan gambar di atas, diketahui bahwa kematian larva Aedes aegypti mulai mengalami kenaikan pada dosis $8 \mathrm{ml}$, dan mengalami kenaikan tinggi pada dosis $16 \mathrm{ml}$ dan terus mengalami kenaikan hingga dosis $20 \mathrm{ml}$.

\section{Analisis Data Hasil Penelitian}

\section{a. Uji Normalitas}

Uji normalitas sampel dilakukan dengan menggunakan uji lilliefors atau uji kolmogorov smirnov (Sudjana, 2006: 466). Pengujian data dalam penelitian ini dengan menggunakan bantuan komputer. Hasil uji lilliefors secara lengkap dapat dilihat pada lampiran, sedangkan rangkuman seperti pada Tabel 4.4 berikut ini:

Tabel 4.4 Rangkuman Hasil Uji Normalitas Sampel pada Taraf Signifikansi $\angle=0,05$

\begin{tabular}{|c|c|c|c|c|c|}
\hline $\begin{array}{c}\text { N } \\
\text { o }\end{array}$ & $\begin{array}{c}\text { Kelompo } \\
\text { k Data }\end{array}$ & $\mathbf{n}$ & $\mathbf{p}$ & \langle & Kesimpulan \\
\hline 1. & $4 \mathrm{ml}$ & 4 & 0,06 & 0,0 & Normal \\
2. & $8 \mathrm{ml}$ & 4 & 0 & 5 & Normal \\
3. & $12 \mathrm{ml}$ & 4 & 0,06 & 0,0 & Normal \\
4. & $16 \mathrm{ml}$ & 4 & 7 & 5 & Normal \\
5. & $20 \mathrm{ml}$ & 4 & 0,40 & 0,0 & Normal \\
& & & 8 & 5 & \\
& & & 0,66 & 0,0 & \\
& & & 4 & 5 & \\
& & & 0,96 & 0,0 & \\
& & & 6 & 5 & \\
\hline
\end{tabular}

Berdasarkan Tabel 4.4 di atas, diketahui bahwa untuk semua kelompok data lebih besar dibandingkan dengan harga alfa atau taraf signifikansi 0,05 atau probabilitas ( $\mathrm{p}<0,05)$, sehingga dapat disimpulkan bahwa data dari semua kelompok sampel berdistribusi normal.

b. Analisis Anova Dua jalan Pengujian hipotesis digunakan teknik analisis anova dua jalan dengan taraf sinifikansi sebesar 95\% $(<=$ 0,05). Perhitungan secara lengkap dapat dilihat pada lampiran, sedangkan rangkumannya seperti pada

Tabel 4.5 sebagai berikut:

Tabel 4.5 Rangkuman Hasil Perhitungan Anova Dua Jalan pada Taraf Sinifikansi $\langle=0,05$

\begin{tabular}{|c|l|c|c|c|}
\hline No & Variabel & $\mathrm{F}$ & $\mathrm{p}$ & Kesimpulan \\
\hline 1. & Dosis & 12,769 & 0,000 & $\mathrm{H}_{0}$ ditolak \\
2. & Jenis & 4,465 & 0,043 & $\mathrm{H}_{0}$ ditolak \\
3. & larvasida & 0,916 & 0,047 & $\mathrm{H}_{0}$ ditolak \\
& Interaksi & & & \\
& konsentrasi & & & \\
& dan janis & & & \\
& larvasida & & & \\
\hline
\end{tabular}

a) Pengaruh Beberapa Dosis Larvasida Alami terhadap Kematian Larva Nyamuk Aedes Aegypti

Hasil perhitungan anova satu faktor seperti pada Tabel 4.5 di atas, diketahui bahwa $\mathrm{F}$ hitung sebesar 12,769 dengan probabilitas 0,000 . Oleh karena probabilitas kurang dari 0,05, maka Ho yang menyatakan bahwa "tidak terdapat pengaruh beberapa dosis larvasida alami terhadap kematian larva nyamuk Aedes aegypti ditolak. Sedangkan hipotesis alternatif yang menyatakan bahwa "ada pengaruh beberapa dosis larvasida alami terhadap kematian larva nyamuk Aedes aegypti diterima, karena kebenarannya terbukti dalam penelitian ini.

b) Pengaruh Jenis Ekstrak Larvasida Alami terhadap Kematian Larva Nyamuk Aedes Aegypti

Hasil perhitungan anova satu faktor pada Tabel 4.5 di atas, juga menunjukkan pengaruh jenis ekstrak larvasida alami terhadap kematian larva nyamuk Aedes aegypti. Berdasarkan Tabel 4.5 di atas, diketahui bahwa F hitung sebesar 4,465 dengan probabilitas 0,043. Oleh karena probabilitas kurang dari 0,05, maka terdapat pengaruh antara jenis ekstrak larvasida alami terhadap kematian larva nyamuk Aedes aegypti.

c) Interaksi antara Beberapa Dosis Dan Jenis Ekstrak Larvasida Alami terhadap Kematian Larva Nyamuk Aedes Aegypti Hasil perhitungan anova dua jalan seperti pada Tabel 4.5 di atas, diketahui bahwa $\mathrm{F}$ hitung sebesar 0,916 dengan probabilitas 0,037. Oleh karena probabilitas kurang dari 0,05, maka Ho yang menyatakan bahwa "tidak terdapat interaksi antara beberapa dosis dan jenis ekstrak larvasida alami terhadap kematian larva nyamuk Aedes aegypti ditolak. Sedangkan hipotesis alternatif yang 
menyatakan bahwa "ada interaksi antara beberapa dosis dan jenis ekstrak larvasida alami terhadap kematian larva nyamuk Aedes aegypti diterima, karena kebenarannya terbukti dalam penelitian ini.

Uji lanjut untuk mengetahui perbedaan pengaruh antar sel dilakukan dengan uji LSD (uji least significance difference). Perhitungan secara lengkap dapat dilihat pada lampiran, sedangkan rangkumannya seperti pada Tabel 4.6 sebagai berikut:

Tabel 4.6 Rangkuman Hasil Uji LSD Interaksi Beberapa Dosis Larvasida Alami terhadap Kematian Larva Nyamuk Aedes Aegypti

\begin{tabular}{|c|c|c|c|c|}
\hline $\begin{array}{c}\text { Kelompok } \\
\text { yang } \\
\text { dibandingkan } \\
\text { dosis }\end{array}$ & $\begin{array}{l}\text { Rata- } \\
\text { rata } \\
\text { Skor }\end{array}$ & $\begin{array}{c}\text { Mea } \\
n \\
\text { Diff } \\
\text { eren } \\
\text { ce }\end{array}$ & $\begin{array}{l}\text { Si } \\
\text { g. }\end{array}$ & $\begin{array}{c}\text { Keteran } \\
\text { gan }\end{array}$ \\
\hline $\begin{array}{l}4 \mathrm{ml} \text { serai }>< \\
8 \mathrm{ml} \text { serai }\end{array}$ & $\begin{array}{c}0,250- \\
0,500\end{array}$ & $\begin{array}{c}- \\
0,25 \\
00\end{array}$ & $\begin{array}{l}0 \\
9 \\
3 \\
3\end{array}$ & $\begin{array}{c}\text { Tidak } \\
\text { signifik } \\
\text { an }\end{array}$ \\
\hline $\begin{array}{l}4 \mathrm{ml} \text { serai }>< \\
16 \mathrm{ml} \text { serai }\end{array}$ & $\begin{array}{c}0,250- \\
6,750\end{array}$ & $\begin{array}{c}- \\
6,50 \\
0\end{array}$ & $\begin{array}{l}0, \\
0 \\
3 \\
6\end{array}$ & $\begin{array}{c}\text { Signifik } \\
\text { an }\end{array}$ \\
\hline $\begin{array}{l}4 \mathrm{ml} \text { serai }>< \\
4 \mathrm{ml} \text { sirsak }\end{array}$ & $\begin{array}{c}0,250- \\
0,500\end{array}$ & $\begin{array}{c}- \\
2,50 \\
0\end{array}$ & $\begin{array}{l}0 \\
9 \\
3 \\
3\end{array}$ & $\begin{array}{c}\text { Tidak } \\
\text { signifik } \\
\text { an }\end{array}$ \\
\hline $\begin{array}{l}4 \mathrm{ml} \text { serai }>< \\
20 \mathrm{ml} \text { sirsak }\end{array}$ & $\begin{array}{c}0,250- \\
15,250\end{array}$ & $\begin{array}{c}- \\
15,0 \\
00\end{array}$ & $\begin{array}{c}0, \\
0 \\
0 \\
0\end{array}$ & $\begin{array}{c}\text { Signifik } \\
\text { an }\end{array}$ \\
\hline $\begin{array}{l}8 \mathrm{ml} \text { serai }>< \\
16 \mathrm{ml} \text { sirsak }\end{array}$ & $\begin{array}{c}0,500- \\
10,750\end{array}$ & $\begin{array}{c}- \\
10,2 \\
500\end{array}$ & $\begin{array}{l}0 \\
0 \\
0 \\
2 \\
\end{array}$ & $\begin{array}{c}\text { Signifik } \\
\text { an }\end{array}$ \\
\hline $\begin{array}{l}8 \mathrm{ml} \text { serai }>< \\
20 \mathrm{ml} \text { sirsak }\end{array}$ & $\begin{array}{c}0,500- \\
15,250\end{array}$ & $\begin{array}{c}- \\
14,7 \\
500\end{array}$ & $\begin{array}{l}0, \\
0 \\
0 \\
0\end{array}$ & $\begin{array}{c}\text { Signifik } \\
\text { an }\end{array}$ \\
\hline $\begin{array}{lcr}16 & \mathrm{ml} & \text { serai } \\
>< & 16 & \mathrm{ml} \\
\text { sirsak } & \end{array}$ & $\begin{array}{c}6,750- \\
10,750\end{array}$ & $\begin{array}{c}- \\
4,00 \\
00\end{array}$ & $\begin{array}{l}0 \\
1 \\
8 \\
7 \\
\end{array}$ & $\begin{array}{c}\text { Tidak } \\
\text { Signifik } \\
\text { an }\end{array}$ \\
\hline $\begin{array}{lcr}20 & \mathrm{ml} & \text { serai } \\
>< & 20 & \mathrm{ml} \\
\text { sirsak } & \\
\end{array}$ & $\begin{array}{c}9,250- \\
15,250\end{array}$ & $\begin{array}{c}- \\
6,00 \\
00\end{array}$ & $\begin{array}{l}0 \\
0 \\
5 \\
2\end{array}$ & $\begin{array}{c}\text { Tidak } \\
\text { Signifik } \\
\text { an }\end{array}$ \\
\hline
\end{tabular}

Berdasarkan data pada Tabel 4.6, dapat diambil kesimpulan sebagai berikut: a) Perbandingan antara kelompok dengan dosis larvasida $4 \mathrm{ml}$ batang serai dengan 8 $\mathrm{ml}$ batang serai, diketahui mean difference $-0,250$ dengan tingkat signifikansi 0,933 dimana lebih dari 0,05, sehingga dapat dikatakan bahwa kedua kelompok sampel tidak mempunyai perbedaan skor yang signifikan. Kesimpulan: kelompok yang diberi dosi larvasida batang serai $4 \mathrm{ml}$ tidak memberi pengaruh yang sama dengan kelompok yang diberi dosis larvasida batang serai $8 \mathrm{ml}$.

b) Perbandingan antara kelompok dengan dosis larvasida $4 \mathrm{ml}$ batang serai dengan $16 \mathrm{ml}$ batang serai, diketahui mean difference -6,500 dengan tingkat signifikansi 0,036 dimana kurang dari 0,05, sehingga dapat dikatakan bahwa kedua kelompok sampel mempunyai perbedaan skor yang signifikan. Kesimpulan: kelompok yang diberi dosis larvasida batang serai $4 \mathrm{ml}$ memberi pengaruh yang berbeda dengan kelompok yang diberi dosis larvasida batang serai 16 $\mathrm{ml}$.

c) Perbandingan antara kelompok dengan dosis larvasida $4 \mathrm{ml}$ batang serai dengan 4 $\mathrm{ml}$ daun sirsak, diketahui mean difference -2,500 dengan tingkat signifikansi 0,933 dimana lebih dari 0,05, sehingga dapat dikatakan bahwa kedua kelompok sampel tidak mempunyai perbedaan skor yang tidak signifikan. Kesimpulan: kelompok yang diberi dosis larvasida batang serai 4 $\mathrm{ml}$ tidak memberi pengaruh yang berbeda dengan kelompok yang diberi dosis larvasida daun sirsak $4 \mathrm{ml}$.

d) Perbandingan antara kelompok dengan dosis larvasida $16 \mathrm{ml}$ batang serai dengan $16 \mathrm{ml}$ daun sirsak, diketahui mean difference $-4,0000$ dengan tingkat signifikansi 0,187 dimana lebih dari 0,05, sehingga dapat dikatakan bahwa kedua kelompok sampel mempunyai perbedaan skor yang tidak signifikan. Kesimpulan: kelompok yang diberi dosis larvasida batang serai $16 \mathrm{ml}$ tidak memberi pengaruh yang berbeda dengan kelompok yang diberi dosis larvasida daun sirsak 16 $\mathrm{ml}$.

e) Perbandingan antara kelompok dengan dosis larvasida $20 \mathrm{ml}$ batang serai dengan $20 \mathrm{ml}$ daun sirsak, diketahui mean difference $-6,0000$ dengan tingkat signifikansi 0,052 dimana lebih dari 0,05, sehingga dapat dikatakan bahwa kedua kelompok sampel mempunyai perbedaan skor yang tidak signifikan. Kesimpulan: kelompok yang diberi dosis larvasida 
batang serai $20 \mathrm{ml}$ tidak memberi pengaruh yang berbeda dengan kelompok yang diberi dosis larvasida daun sirsak 20 $\mathrm{m}$

\section{a. Analisis Probit}

Setelah dilakukan analisis probit dengan menggunakan program computer dengan tingkat kepercayaan 95\%, diketahui bahwa dosis ekstrak daun sirsak yang dapat mengakibatkan kematian larva $50 \%$ adalah dosis 17,815 ppm dengan interval antara 16,708 ppm dan 19,260 ppm dan pada waktu paparan yang dapat mengakibatkan kematian 50\% larva adalah 60,849 menit dengan interval 6,382 menit dan 82,693 menit. Sedangkan pada larvasida ekstrak batang serai yang dapat mengakibatkan kematian larva 50\% adalah dosis 22,696 ppm dengan interval antara 20,424 ppm dan 27,638 ppm dan pada waktu paparan yang dapat mengakibatkan kematian 50\% larva adalah 79,507 menit dengan interval 65,906 menit dan 171,864 menit.

Table 4.7 Hasil Analisis Probit

\begin{tabular}{lcccc}
\hline \multicolumn{5}{c}{$95 \%$ confidence limits for konsentrasi } \\
\hline $\begin{array}{c}\text { Jenis } \\
\text { larvasid } \\
\text { a }\end{array}$ & $\begin{array}{c}\text { Probabilit } \\
\text { y }\end{array}$ & $\begin{array}{c}\text { Estimat } \\
\text { e }\end{array}$ & $\begin{array}{c}\text { Lowe } \\
\mathrm{r} \\
\text { bound }\end{array}$ & $\begin{array}{c}\text { Upper } \\
\text { bound }\end{array}$ \\
\hline $\begin{array}{l}\text { Batang } \\
\text { serai }\end{array}$ & 0,5 & 22,696 & $\begin{array}{c}20,42 \\
4\end{array}$ & $\begin{array}{c}27,63 \\
8\end{array}$ \\
\hline $\begin{array}{l}\text { Daun } \\
\text { sirsak }\end{array}$ & 0,5 & 17,815 & $\begin{array}{c}16,70 \\
8\end{array}$ & $\begin{array}{c}19,26 \\
0\end{array}$ \\
\hline
\end{tabular}

\section{B. Pembahasan}

\section{a. Pembahasan Umum}

Laboratorium Kampus 7 Poltekkes Kemenkes Semarang Jurusan Kesehatan Lingkungan Purwokerto didirikan pada tanggal 1 Januari 1979 yang berfungsi untuk pembelajaran mahasiswa Jurusan Kesehatan Lingkungan serta melayani pemeriksaan sampel untuk kepentingan penelitian dosen dan mahasiswa. Laboratorium Kampus 7 Poltekkes Kemenkes Semarang Jurusan Kesehatan Lingkungan Purwokerto berada di Kampus 7 Poltekkes Semarang Jalan Raya Baturraden KM 12 Kotak pos 148 Telp/Fax : 0281-681709 Desa Karangmangu, Kecamatan Baturraden, Purwokerto. Aktivitas di Laboratorium Kesehatan Lingkungan dimulai dari pukul 08.00 WIB sampai 16.00 WIB.

Laboratorium Kampus 7 Poltekkes Kemenkes Semarang Jurusan Kesehatan Lingkungan dibagi menjadi lima bagian diantaranya adalah laboratorium
Mikrobiologi, Kimia, K3, Fisika, Biologi termasuk didalamnya parasitologi, Entomologi dan Vektor. Kemampuan Laboratorium Jurusan Kesehatan Lingkungan yaitu mampu melakukan kegiatan praktikum dari semua bidang studi yang didalamnya terdapat pembelajaran praktikum baik dilaboratorium maupun di workshop.

\section{b. Pembahasan Khusus}

1. Suhu

Suhu media sebagai variable yang dapat mempengaruhi hasil penelitian, maka dari itu suhu media juga harus diukur dan dikendalikan dengan cara menempatkan media uji pada ruangan sehingga suhunya akan stabil. Pengukuran suhu pada media tempat pengujian dari awal sampai akhir selama pengamatan 24 jam, didapatkan hasil dimana suhu pada media uji stabil yaitu pada angka $25^{\circ} \mathrm{C}$. Suhu pada masingmasing media uji tersebut tidak mempengaruhi pertumbuhan larva karena termasuk dalam kriteria suhu yang optimum untuk pertumbuhan larva Aedes aegypti yaitu pada suhu $25^{\circ} \mathrm{C}-$ $35^{\circ} \mathrm{C}$ (Ni Luh Putu M, 2004: 4). Berdasarkan hasil pengukuran yang dilakukan tersebut, dapat disimpulkan bahwa bila terjadi perbedaan jumlah kematian pada larva Aedes aegypti antar media uji, maka perbedaan tersebut tidak disebabkan oleh suhu media uji.

2. $\mathrm{pH}$

$\mathrm{pH}$ media merupakan variabel perancu yang dapat mempengaruhi hasil penelitian, maka dari itu $\mathrm{pH}$ media harus diukur untuk mengetahui perubahan $\mathrm{pH}$ pada media akibat penambahan ekstrak daun sirsak dan ekstrak batang serai tersebut. Pada pengukuran $\mathrm{pH}$ masingmasing media uji, pada kelompok kontrol menunjukkan $\mathrm{pH}$ air normal yaitu 7, sedangkan penambahan ekstrak daun sirsak dan ekstrak batang serai pada kelompok intervensi mengakibatkan penambahan keasaman $\mathrm{pH}$ media uji yaitu menjadi 5. Akan tetapi hal ini tidak mempengaruhi kematian larva Aedes aegypti karena larva Aedes aegypti dapat tumbuh pada kisaran pH 4,4 - 9,3. Berdasarkan pengukuran, bahwa bila terjadi perbedaan jumlah kematian pada larva Aedes aegypti antar media uji, maka perbedaan tersebut tidak disebabkan oleh $\mathrm{pH}$ pada media uji. 
3. Umur Larva Aedes aegypti

Pada saat penelitian menggunakan larva Aedes aegypti instar III, dimana pada umur tersebut larva Aedes aegypti sudah memiliki morfologi yang sempurna, sehingga penggunaan larvasida ini dapat diaplikasikan pada larva Aedes aegypti pada berbagai instar. Oleh karena itu, apabila terjadi perbedaan jumlah kematian Aedes aegypti antar media uji, maka pebedaan tersebut tidak disebabkan oleh umur larva.

4. Waktu Kontak

Waktu kontak larvasida dari ekstrak daun sirsak dan ekstrak batang serai dengan larva Aedes aegypti disamakan yaitu selama 24 jam, karena pada kurun waktu tersebut suatu insektisida sudah dapat aktif bekerja. Hal ini menunjukkan bahwa apabila terjadi perbedaan jumlah kematian larva Aedes aegypti antar media uji, maka perbedaan tersebut tidak disebabkan oleh waktu kontak terhadap larvasida.

A. Pengaruh antara Beberapa Dosis Ekstrak Larvasida Alami terhadap Kematian Larva Nyamuk Aedes aegypti

Hasil pengujian hipotesis menunjukkan adanya pengaruh antara beberapa dosis ekstrak larvasida alami terhadap kematian larva nyamuk Aedes aegypti. Dari perbandingan antara mean kelompok yang mendapatkan dosis $4 \mathrm{ml}, 8$ $\mathrm{ml}, 12 \mathrm{ml}, 16 \mathrm{ml}$ dan $20 \mathrm{ml}$, ternyata jentik yang mati terdapat pada kelompok dengan dosis $20 \mathrm{ml}$ lebih baik dari pada kelompok dengan dosis di bawahnya. Berdasarkan table 4.3, diketahui bahwa rata-rata kematian larva pada nyamuk Aedes aegypti mengalami peningkatan jumlah seiring dengan peningkatan jumlah dosis larvasida yang diberikan.

Ekstrak larvasida dengan dosis $4 \mathrm{ml}$ dikatakan tidak efektif mematikan larva Aedes aegypti karena setelah pengamatan selama 24 jam diperolah rata-rata kematian larva Aedes aegypti sebesar 0,25\%, kematian larva $\leq 50 \%$ hal tersebut disebabkan oleh umur stadium larva yang digunakan untuk penelitian tidak sama. Efek racun kontak larvasida alami dengan dosis yang semakin tinggi mampu menghambat transport electron pada system respirasi sel sehingga menyebabkan gradient proton terhambat dan cadangan energy tidak dapat membentuk ATP. Akibatnya aktivitas larva terhambat, gerakan lambat, aktivitas makan berkurang, larva berkerut dan akhirnya mati (Kasmawati, 2011).

Ekstrak larvasida alami dengan dosis $20 \mathrm{ml}$ efektif mematikan larva Aedes aegypti selama 24 jam pengamatan. Rata-rata kematian larva nyamuk mengalami peningkatan pada masing-masing dosis. Hal ini disebabkan oleh dosis yang diberikan lebih besar. Kematian larva nyamuk dengan dosis larvasida sebesar $20 \mathrm{ml}$ sangat cepat dibandingkan dengan perilaku larva pada dosis dibawahnya. Setelah beberapa jam kemudian larva terlihat diam dengan posisi menggantung dipermukaan air dalam waktu yang cukup lama sampai akhirnya mati. Karena larva Aedes aegypti kekurangan energi untuk bergerak lagi akibat racun dari ekstrak larvasida alami langsung menyerang sel larva Aedes aegypti. Karena ekstrak larvasida alami yang bersifat racun kontak sehingga racun tersebut masuk kedalam jentik melalui kulit tubuh dan bagian kaki (Kusnadi, 2005).

Semakin tinggi dosis perlakuan semakin banyak jumlah larva yang mati. Hal ini disebabkan kandungan bahan kimia pada ekstrak larvasida alami mengandung senyawa yang mempunyai toksisitas yang tinggi akan tetapi adanya ambang batas yang diperhatikan terhadap penggunaan bahan kimia pada air karena hal tersebut dapat berpotensi untuk mempengaruhi organisme pada air yang lainnya. Dari penilitian yang dilakukan oleh Sugeng (1997) dalam Hafriani (2014) mengenai "Daya Insektisida Daun dan Biji Sirsak Terhadap Larva Nyamuk di Laboratorium”, bahwa biji dan daun sirsak mengandung senyawa bioaktif yang dikenal dengan asetogenin dimana terbukti berdaya insektisidal. Dari hasil penelitian tersebut dengan menggunakan metode infusa pada daun sirsak, didapati infusa $10 \%$ berdaya insektisidal. Selama 24 jam pengamatan dengan $\mathrm{LC}_{50}$ dan CL95\% mempunyai efektifitas sebesar 6,89\% dan selama 48 jam pengamatan efektifitas yang didapat sebesar 5,58\%.

Berdasarkan penelitian Kasmawati tahun 2011 yang menyatakan bahwa senyawa aktif dalam ekstrak larvasida alami mampu menghambat sistem gerak yang dimiliki oleh larva Aedes aegypti. Akibatnya 
aktivitas larva terhambat, gerakan lambat, aktivitas makan berkurang, larva berkerut dan akhirnya mati.

Efek racun kontak ekstrak larvasida alami terlihat dari gejala klinis yang timbul pada larva Aedes aegypti yaitu gerakannya menjadi lamban/ tidak bergerak dalam jangka waktu yang cukup lama dengan posisi menggantung akhirnya mati. Gejala tersebut mengindikasikan bahwa larva kehabisan energi dan keadaan ini sesuai dengan mekanisme kerja senyawa bioaktif ekstrak larvasida alami pada tingkat seluler. Maka dari itu konsentrasi 20ml dapat diaplikasikan dimasyarakat untuk penampungan air yang berada di luar rumah seperti pot bunga.

Pengendalian secara kimia seperti misalnya penggunaan bubuk abate pada larva seringkali dilakukan akan tetapi penggunaan bahan kimia bubuk abate mempunyai sisi negatif pada penggunaanya, dapat menyebabkan pencemaran lingkungan dan dapat menyebabkan resisten pada jentik (Hafriani, 2014). Ekstrak larvasida alami dapat dikembangkan sebagai larvasida yang ramah lingkungan. Selain itu, penggunaan ekstrak daun sirsak dan batang serai ini sangat menguntungkan karena bahannya mudah didapat dan mudah aplikasinya. Oleh karena itu, salah satu cara yang dapat dilakukan untuk mencegah penyakit DBD yaitu dengan cara pengendalian hayati dengan menggunakan larvasida yang terbuat dari tumbuhan. Salah satunya yaitu dengan pemanfaatan tanaman daun sirsak. Dengan pertimbangan bahwa tidak membahayakan makhluk hidup yang bukan merupakan target, efektif terhadap larva nyamuk, dan mempunyai daya sebar yang baik didalam air dari tempat perindukan dan didalam tangkii kemudian disemprotkan (Kasmawati, 2011).

\section{B. Pengaruh Jenis Ekstrak Larvasida Alami terhadap Kematian Larva Nyamuk Aedes aegypti}

World Health Organization (WHO) telah menerbitkan pedoman laboratorium pada tahun 2005 yang ditujukan untuk bidang pengujian larvasida dengan membuat prosedur mekanisme pengujian larvasida yang baku. Dalam pengujiannya, suatu potensi senyawa sebagai insektisida harus dibandingkan dengan insektisida lainnya. Sampai saat ini WHO belum menetapkan kriteria standar dalam menentukan aktivitas larvasida alami, sehingga banyak penulis membuat karakteristik sendiri untuk potensi larvasida produk alami.

Indonesia memiliki banyak ragam jenis tanaman dan telah dimanfaatkan oleh banyak orang untuk berbagai keperluan, salah satunya sebagai pengembangan bahan aktif untuk insektisida nabati sebagai alternatif pengganti insektisida kimia. Berdasarkan hasil pengelompokan larvasida nabati oleh Komalamisra et al maka dapat dianggap bahwa ada 68\% spesies tanaman yang menghasilkan minyak atsiri yang termasuk dalam kategori aktif $\mathrm{LC}_{50}<750$ ppm yaitu serai dapur, zodia, melati, nilam, tembakau, lengkuas, serai wangi, kayu jati, pohon tanjung, kayu putih, daun sirih, jeruk manis, sirsak, legundi, karika, buah pare dan ceremai. Tanaman-tanaman tersebut memiliki aktivitas larvasida yang tinggi dengan senyawa aktif yang berbeda-beda. Berdasarkan hasil penelusuran pustaka maka dapat dianggap bahwa 68\% spesies tanaman yang menghasilkan minyak atsiri yang termasuk dalam kategori aktif $\mathrm{LC}_{50}<750$ ppm yaitu serai dapur, zodia, melati, nilam, tembakau, lengkuas, serai wangi, kayu jati, pohon tanjung, kayu putih, daun sirih, jeruk manis, sirsak, legundi, karika, buah pare dan ceremai. Tanaman-tanaman tersebut memiliki aktivitas larvasida yang tinggi dengan senyawa aktif yang berbeda-beda.

Hasil pengujian hipotesis menunjukkan adanya pengaruh jenis ekstrak larvasida alami terhadap kematian larva nyamuk aedes aegypti. Dari perbandingan antara mean kelompok yang mendapatkan ekstrak larvasida alami berupa daun sirsak lebih baik daripada kematian larva pada kelompok dengan pemberian ekstrak batang serai. Berdasarkan tabel 4.3, diketahui bahwa rata-rata kematian larva pada nyamuk aedes aegypti mengalami peningkatan jumlah pada jenis larvasida yang diberikan berupa daun sirsak.

Daun sirsak memiliki bahan reaktif yaitu annonain dan squamosin yang dapat menyebabkan terjadinya kematian larva (mortalitas) Aedes aegypti. Hal ini disebabkan bahan tersebut berfungsi sebagai racun pernafasan pada larva. Berdasarkan pengamatan perilaku larva Aedes aegypti setelah perlakuan ekstrak daun sirsak (Annona muricata) diperoleh bahwa larva Aedes aegypti bergerak lamban karena racun tersebut bekerja langsung pada jentik sasaran yang sesuai dengan cara kerja racun kontak (Kusnadi, 2005). Komponen aktif yang terdapat dalam daun sirsak seperti monoterpen dan terpena memiliki efek 
larvasida yaitu dengan cara mengganggu susunan saraf pada larva serta menghambat pertumbuhan larva dengan cara menghambat daya makan larva.

Penelitian yang dilakukan oleh Freddy (2005) dalam Rosmayanti (2011) menunjukkan bahwa ekstrak etanol dari annona muricata memiliki kadar annonacin yang paling tinggi dibandingkan dengan pelarut yang lain seperti etil asetat. Cara kerja acetogenin adalah dengan menghambat rantai pernapasan pada NADH ubiquinone reduktase ( complex 1 ) yang menyebabkan penurunan kadar adenosine triphosphat ( ATP ), menyebabkan secara langsung gangguan transport elektron di mitokondria sehingga memacu apopotosis sel. Ekstrak tanaman famili Annonaceous telah banyak di teliti sebagai insektisida dan larvasida seperti Aedes aegypti dan lepidoptera larvae.

Senyawa bioaktif yang terdapat didalam ekstrak daun sirsak yaitu annonain dan squamosin yang termasuk dalam golongan asetogenesin. Berdasarkan penelitian Kasmawati tahun 2011 yang menyatakan bahwa senyawa aktif dalam ekstrak daun sirsak yaitu squamosin mampu menghambat sistem gerak yang dimiliki oleh larva Aedes aegypti. Akibatnya aktivitas larva terhambat, gerakan lambat, aktivitas makan berkurang, larva berkerut, dan akhirnya mati.

\section{Interaksi antara Beberapa Dosis Dan} Jenis Ekstrak Larvasida Alami terhadap Kematian Larva Nyamuk Aedes aegypti Hasil pengujian hipotesis menunjukkan adanya pengaruh beberapa dosis dan jenis ekstrak larvasida alami terhadap kematian larva nyamuk Aedes aegypti. Ada banyak faktor yang mempengaruhi kematian larva nyamuk Aedes aegypti. Salah satu yang berpengaruh adalah dosis larvasida yang diberikan dan jenis larvasidanya.

Larvasida nabati yang diperoleh dari tanaman berbeda tentu memperlihatkan aktivitasnya yang berbeda meskipun berasal dari satu famili yang sama. Dominasi kandungan komponen penyusunnya antar famili satu dengan famili lainnya akan berbeda sehingga menghasilkan daya bunuh larva nyamuk berbeda pula. Menurut Purnomo, Asmarayani R, perbedaan tersebut terjadi karena adanya variasi kimia yang merespon terhadap perbedaan faktor luar di habitatnya.
Berdasarkan pada uji laboratorium didapatkan kematian larva nyamuk aedes aegypti pada dosis $4 \mathrm{ml}, 8 \mathrm{ml}, 12 \mathrm{ml}, 16$ $\mathrm{ml}$ dan $20 \mathrm{ml}$. Tujuan perlakuan ini untuk menentukan $\mathrm{LC}_{50}$ yang nantinya akan digunakan sebagai acuan penggunaan larvasida. Hasil uji menunjukkan bahwa semakin besar konsentrasi larvasida yang diberikan maka akan semakin besar pula kematian larva nyamuk Aedes aegypti.

Sejalan dengan pemberian konsentrasi larvasida alami, ternyata jenis larvasida juga mempengaruhi besarnya kematian larva nyamuk. Hasil penelitian menunjukkan bahwa penggunaan larvasida dengan ekstrak daun sirsak lebih banyak menyebabkan kematian pada larva nyamuk dibandingkan pada penggunaan ekstrak batang serai.

Kemampuan larvasida dari ekstrak serai dihasilkan dari beberapa senyawa kimia yang berada didalam tumbuhan tersebut. Adapun fitokimia dalam serai adalah tannin dan saponin. Tannin merupakan phenolic compounds yang dapat mempresipitasi protein. Salah satu fungsinya adalah sebagai pelindung tanaman dari serangga, sehingga memiliki kemampuan untuk mempresipitasi protein. Pada larva hal ini dapat menghambat protein yang diperlukan larva untuk pertumbuhan, sehingga dapat menyebabkan larva mati.

Saponim dapat menyebabkan korosi dinding traktus digestivus larva dikarenakan kemampuan saponin merusak membrane. Selain itu saponin juga dapat mengganggu lapisan lipoid pada epikutikula dan lapisan protein pada endokutikula sehingga memudahkan zat toksik masuk kedalam tubuh larva. Namun setelah dibandingkan dengan ekstrak tanaman lain yang diuji kemampuannya terhadap Aedes aegypty, didapatkan bahwa ekstrak tanaman serai mempunyai kemampuan lebih rendah. Misalnya penelitian yang dilakukan oleh Anggraeni, menggunakan ekstrak buah cabe jawa didapatkan $\mathrm{LC}_{50}$ sebesar 3,9 ppm.

Berdasarkan hasil diatas menunjukkan bahwa pada konsentrasi 20ml ekstrak daun sirsak (Annona muricata) telah cukup efektif untuk membunuh larva Aedes aegypti karena telah memenuhi $\mathrm{LC}_{50}$ sedangkan pada konsentrasi $4 \mathrm{ml}$ tidak cukup efektif untuk membunuh jentik Aedes aegypti karena tidak memenuhi $\mathrm{LC}_{50}$, dimana Lethal Consentrat 50 adalah konsentrasi tertentu 
suatu bahan yang mampu mematikan sebanyak 50\% hewan percobaan.

Uji toksisitas dilakukan dengan memberikan zat yang sedang diuji sebanyak satu kali dalam jangka waktu 24 jam. LC $_{50}$ adalah kadar yang menyebabkan kematian 50\% hewan pada pajanan selama waktu tertentu. Pada penelitian jangka pendek, lama penelitian biasanya 30 atau 90 hari, dan pada penelitian jangka panjang 1 tahun atau lebih (Lu, 2010).

Semakin tinggi konsentrasi perlakuan semakin banyak jumlah larva yang mati. Hal ini disebabkan kandungan bahan kimia pada ekstrak daun sirsak mengandung senyawa acetogenin yang mempunyai toksisitas yang tinggi akan tetapi adanya ambang batas yang diperhatikan terhadap penggunaan bahan kimia pada air karena hal tersebut dapat berpotensi untuk mempengaruhi organisme pada air yang lainnya. Dari penilitian yang dilakukan oleh Sugeng (1997) dalam Hafriani (2014) mengenai "Daya Insektisida Daun dan Biji Sirsak Terhadap Larva Nyamuk di Laboratorium”, bahwa biji dan daun sirsak mengandung senyawa bioaktif yang dikenal dengan asetogenin dimana terbukti berdaya insektisidal. Dari hasil penelitian tersebut dengan menggunakan metode infusa pada daun sirsak, didapati infusa $10 \%$ berdaya insektisidal. Selama 24 jam pengamatan dengan $L_{50}$ dan CL95\% mempunyai efektifitas sebesar $6,89 \%$ dan selama 48 jam pengamatan efektifitas yang didapat sebesar 5,58\%.

\section{Kesimpulan}

1. Ada pengaruh antara beberapa dosis ekstrak larvasida alami terhadap kematian larva nyamuk Aedes aegypti.

2. Ada pengaruh jenis ekstrak larvasida alami terhadap kematian larva nyamuk Aedes aegypti.

3. Ada interaksi antara beberapa dosis dan jenis ekstrak larvasida alami terhadap kematian larva nyamuk Aedes aegypti.

\section{DAFTAR PUSTAKA}

Aris Santjaka, 2011, Statistik Untuk Penelitian Kesehatan 1, Yogyakarta: Nuha Medika

Aryu Candra, 2010, Demam Berdarah Dengue: Epidemiologi, Patogenesis, dan Faktor Risiko Penularan, Staf Pengajar FK-UNDIP Semarang
Ari Kuncoro, 2007, Efektivitas Daya Bunuh Serbuk Biji dan Ekstrak Daun Sirsak (Annona muricata) Terhadap Larva Nyamuk Aedes aegypti, Universitas Muhammadiyah surakarta

Anggraeni, 2015, Uji Efektivitas Larvasida Buah Cabe Jawa Terhadap Kematian Jentik Nyamuk, FK-Kedokteran Brawijaya Malang

Bahila, Fathan, Hiola, Rama, Amalia dan Lia, 2015, Uji Efektifitas Ekstrak Daun Sirsak (Annona muricata L.) Dan Daun Rambutan (Nephelium lappaceum L.) Terhadap Kematian Larva Aedes aegypti, http://eprints.ung.ac.id, diakses tanggal 8 November 2016 jam 20:14

Cecep Dani Sucipto, 2011, Vektor Penyakit Tropis, Yogyakarta: Gosyen Publishing

Departemen Kesehatan R.I, 2010, Pemberantasan Nyamuk Penular Demam Berdarah Dengue, Jakarta: Departemen Kesehatan Republik Indonesia.

Harborne JB, 1997, Metode Fitokimia : Penentuan Cara Modern Menganalisa Tumbuhan, Bandung : ITB Press

Komariah, Seftiani Pratita dan Tan Malaka, 2010, Pengendalian Vektor, Jurnal Kesehatan Bima Husada Vol. 6 No. 1

Kardinan, 2000, Pestisida Nabati: Ramuan dan Aplikasinya, Jakarta : Penebar Swadaya.

Kusnadi Chasan S. 2005. Pengendalian Vektor Dan Binatang Pengganggu. Makassar: Jurusan Kesling Poltekkes Makassar.

Kasmawati, 2011. Study Pemanfaatan Ekstrak Biji Srikaya (Annona Squamosa Linn) Sebagai Larvasida Pada Aedes aegypti. Makassar: Jurusan Kesehatan Lingkungan Politeknik Kesehatan Makassar. (KTI Tidak Diterbitkan.

Nadyawatie Warganegara, 2014, Pengaruh Ekstrak Serai (Andropogon nardus) Terhadap Kematian Larva Nyamuk Aedes aegypti, http://eprints.ug.ac.id diakses tanggal 8 November 2016 jam 20:36

Profil Kesehatan Kota Semarang Tahun 2015, Kota Semarang: Dinas Kesehatan Kota Semarang. 
Rosmayanti Kiki, 2011. Uji Efektivitas Ekstrak Biji Sirsak repository.uinjkt.ac.id/dspace/bitstream/12 3456789/25762/KIKI\%ROSMAYANTI. pdf. Diakses 10 januari 2016.

Sukma Wardani, 2009, Uji Aktivitas Minyak Atsiri Daun Dan Batang Serai (Andropogon nardus L) Sebagai Obat Nyamuk Elektrik Terhadap Nyamuk Aedes aegypti, Skripsi: Universitas Muhammadiyah surakarta

Sri Wahyuni, 2005, Daya Bunuh Ekstrak Serai (Andropogon nardus) terhadap nyamuk Aedes aegypti, Skripsi: Universitas Negri Semarang

Sugeng Juwono, 1992, Daya Insektisida Daun dan Biji Annona muricata Linn Terhadap Larva Nyamuk di Laboratorium, Jurnal Fakultas Kedokteran Universitas Gajah Mada, Vol 24 No. 3

Suyanto S, Darnoto, dan D. Astuti, 2011, Hubungan Pengetahuan dan sikap dengan praktek pengendalian nyamuk Aedes aegypti di Kelurahan Sangkrah Kecamatan Pasar Kliwon Kota Surakarta, Jurnal Kesehatamn, 4 :1-13

Tri Cahyono, 2014, Pedoman Penulisan Proposal Penelitian Dan Karya Tulis Ilmiah / Skripsi (Edisi Revisi Ketiga), Purwokerto: Kementrian Kesehatan RI Politeknik Kesehatan Depkes Semarang Jurusan Kesehatan Lingkungan

Yanuar Setyaningrum, Sholihah, Ifan Prasetya Yuda dan Husumah, 2007, Serai (Andropogon nardus) Sebagai Insektisida Pembasmi Aedes Aegypti Semua Stadium. Malang. Universitas Muhamadiyah Malang 